\title{
MMM Technique for Non Destructive Evaluation of Surfaces
}

\author{
Anna Mičietová1, Mária Čilliková1 ${ }^{1}, K$ amil Kolař́ik ${ }^{2}$, Miroslav Neslušan ${ }^{1}$, Václav Svoboda ${ }^{3}$ \\ ${ }^{1}$ ŽU Žilina, Univerzitná 1, 01026 Žilina, KOVT, SjF, E-mail: anna.mičietova@fstroj.uniza.sk \\ ${ }^{2}$ ČVUT Praha, Trojanova 13, 120 00, Praha 2, ČR \\ ${ }^{3}$ Preditest, s.r.o. Novodvorská 14, 140 02, Praha 4, ČR
}

This paper deals with non destructive evaluation of surfaces via progressive method based on Metal Magnetic Memory (MMM). The paper reports about the physical background of this technique as well as presents specific results of some tests carried out on industrial and laboratory surfaces. This method seems to be promising techniques for fast and reliable monitoring components exposed to the surface modification as well as degradation under the external mechanical and other loads. The paper also discusses some advantages and disadvantages of this technique and presents some examples in which real components are monitored by the use of this technique.

Keywords: metal magnetic memory, non destructive evaluation, cracking

\section{Acknowledgements}

This article was edited under the financial support of KEGA projects n. 009ŽU - 4/2014.

\section{References}

[1] MIČÚCH, M. et all. (2014). Micro magnetic study of cutting conditions and grinding wheel wear influence on surface integrity, Manufacturing Technology, Vol. 14, 2014, pp. 66-71.

[2] NESLUŠAN, M. et.all (2012). Application of Barkhausen noise for analysis of surface integrity after hard turning, Manufacturing technology, Vol. 12, 2012, pp. 60-65.

[3] Preditest, M. Inspection by the use of $M M M$, information bulletin, www.preditest.cz.

[4] HAJKO, V. POTOCKÝ, L., ZENTKO, A. (1982). Magnetization processes, ALFA Bratislava, 1982.

[5] MARTINÉZ-ORTIZ, M. et all. (2015). On the estimation of the magnetic easy axis in pipe line steel, Journal of Magnetism and Magnetic Materials, Vol. 374, 2015, p. 67 - 74.

[6] DUBOV, A. A. (1995). Diagnostics of boiler tubes with usage of MMM, Moskow, Energoamizdat, 1995 , p. 112. 